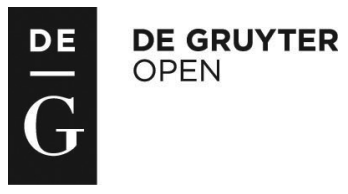

\title{
IN VITRO DEGRADABILITY, GAS PRODUCTION, AND ENERGY VALUE OF DIFFERENT HYBRIDS OF SORGHUM AFTER STORAGE IN MINI-SILOS*
}

\author{
Mirko Cattani $^{1 \bullet}$, Alberto Sartori ${ }^{2}$, Valerio Bondesan ${ }^{2}$, Lucia Bailoni ${ }^{1}$ \\ ${ }^{1}$ Department of Comparative Biomedicine and Food Science, University of Padova, \\ Viale dell'Università 16, 35020 Legnaro (Padova), Italy \\ ${ }^{2}$ Veneto Agricoltura Agency, Viale dell'Università 14, 35020 Legnaro (Padova), Italy \\ •Corresponding author: mirko.cattani@unipd.it
}

\begin{abstract}
This experiment compared silages obtained from 3 hybrids of sorghum grown on 2 farms of the Po Valley (one irrigated and one not), in terms of in vitro degradability, gas production (GP), and energy value. Hybrids (forage, sweet or grain genotypes) were sown in experimental plots (3 plots $\times 3$ hybrids), harvested at late-milk stage of maturity, and ensiled into mini-silos ( 3 silos $\times 3$ hybrids) for $60 \mathrm{~d}$. After ensiling, silages were analyzed for composition and fermentation profile. Two incubations (at $48 \mathrm{~h}$ ) were carried out to measure NDF degradability (NDFd), GP, and the metabolizable energy (ME) content of silages. Data of silage composition were submitted to ANOVA, considering farm $(\mathrm{F})$, hybrid $(\mathrm{H})$, and $\mathrm{F} \times \mathrm{H}$ interaction as variation sources. Incubation (run) was also considered as a fixed effect in the statistical model for the parameters obtained by in vitro incubation (NDFd, GP, and energy content). On the irrigated farm (Farm 2), the DM contents of silages were higher than those of the non-irrigated one $(\mathrm{P}<0.001)$ and the fermentation profile was more favorable. Values of GP at 24 and $48 \mathrm{~h}$ and ME content were higher $(\mathrm{P}<0.05)$ for silages of Farm 2 in comparison with Farm 1. Within hybrids, the grain sorghum revealed the greatest DM content whereas the forage sorghum, as expected, was the richest in fibrous fraction content, followed by the sweet and grain genotypes $(\mathrm{P}<\mathbf{0 . 0 0 1})$. Consequently, values of GP were significantly $(\mathrm{P}<0.01)$ influenced by hybrid $(167,200,215 \mathrm{ml} / \mathrm{g} \mathrm{DM}$ and 229, 257, $267 \mathrm{ml} / \mathrm{g} \mathrm{DM}$ for forage, sweet and grain genotypes after 24 and $48 \mathrm{~h}$ of incubation, respectively). The $\mathrm{F} \times \mathrm{H}$ interaction was significant for all considered parameters excluding $\mathrm{DM}$, lignin, ash, $\mathrm{pH}$, and in vitro parameters. On the two farms, in general, forage and grain genotypes were largely different, whereas the sweet sorghum was quite similar to the forage in one case or grain in the other. Results of this experiment highlight the large variability of the nutritional values of sorghum hybrids grown in different conditions.
\end{abstract}

Key words: sorghum hybrids, sorghum silage, in vitro degradability, in vitro gas production

* Work financed by Veneto Agricoltura Agency.

Project title "Alternative crops rotation to contain diffusion of Diabrotica virgifera virgifera LeConte". 
Silages obtained from sorghums belonging to conventional forage and grain genotypes were found to be valid feed sources for dairy cows (Dann et al., 2008; Colombini et al., 2012). In the last years, the potential of sorghum silage as ruminant feed has been evaluated also in Europe. Results would suggest that the inclusion of such feed ingredient in dairy cow diets should be carefully considered, as partial replacement, i.e., to corn silage (Colombini et al., 2010, 2012; Śliwiński et al., 2012). Sweet sorghum represents a particular cultivar with a high content of sugars (70-80\% sucrose) and, to date, it has mostly been used in energy plants for ethanol and biofuel production. However, for its specific chemical profile, some seed companies have been promoting sweet sorghum as a possible crop for silage production and ruminant feeding. Over the last few years in vitro gas production (GP) technique has been largely adopted to evaluate fermentation of ruminant feeds, because it is a fast and cost-effective analysis (Rymer et al., 2005). To date, only the study of Di Marco et al. (2009) has explored the fermentative properties of sweet sorghum silage, when incubated in vitro with rumen fluid, in comparison with forage and grain genotypes. Thus, this research is aimed at comparing in vitro degradability, GP, and energy value of silages obtained from forage, sweet, and grain sorghum grown in two farms located in the Po Valley (Northern Italy).

\section{Material and methods}

Three hybrids of Sorghum vulgare spp. were used: a forage sorghum (Bulldozer), promoted for its high biomass yield and traded by KWS Italia Spa (Monselice, Padova, Italy), a sweet sorghum (Surgo) and a grain sorghum (Favorite), both traded by SIVAM Spa (Casalpusterlengo, Lodi, Italy). Plants were grown in two pilot farms of the Veneto Agricoltura Agency, one (Farm 1) located in the province of Venice (Vallevecchia, latitude $45.6^{\circ} \mathrm{N}$, longitude $12.9^{\circ} \mathrm{E} ; 0 \mathrm{~m}$ above sea level) and one (Farm 2) located in the province of Rovigo (Ceregnano, latitude $45.0^{\circ} \mathrm{N}$, longitude $11.9^{\circ} \mathrm{E}$; $5 \mathrm{~m}$ above sea level). The farms were involved in a project aiming to evaluate quality of silages obtained from different genotypes of sorghum. In each farm, sorghums were sown in nine experimental plots (three plots per hybrid) with an area of 0.2 ha each. Sowing took place in the first ten days of June for all genotypes. No fertilizers were applied; urea $(100 \mathrm{~kg} / \mathrm{ha})$ and herbicides were distributed at post-emergence phase. Irrigation of plants occurred only in Farm 2 (on July 2), as the Farm 1 is not equipped with an irrigation system. Sorghums were harvested on September 18, 2013 in Farm 1 and on September 12, 2013 in Farm 2, in order to collect from both sites plants at a late-milk stage of maturity. The chemical composition of fresh forages was the following (expressed as mean value of the two farms): $24.6 \% \mathrm{DM}$; $5.0 \% \mathrm{CP}, 60.5 \% \mathrm{NDF}, 6.1 \%$ starch, $6.1 \%$ ash, for the forage sorghum (Bulldozer); $27.1 \%$ DM, 5.8\% CP, 58.5\% NDF, 9.2\% starch, 6.2\% ash, for the sweet sorghum (Surgo); 33.1\% DM, 8.1\% CP, 55.5\% NDF, 21.0\% starch, 6.6\% ash, for the grain sorghum (Favorite). After harvest, three aliquots of chopped forage (10 kg each) were prepared for each hybrid, as a representative sample of the three experimen- 
tal plots, homogeneously mixed, and mechanically compacted into nine laboratory mini-silos ( 3 silos $\times 3$ hybrids) with 201 capacity, using a press equipped with a manometer and a hydraulic cylinder generating a compressive force of $1.2 \mathrm{~atm} / \mathrm{cm}^{2}$. The mini-silos were hermetically closed and stored for $60 \mathrm{~d}$ at $24 \pm 3^{\circ} \mathrm{C}$. On opening the mini-silos, the upper layer $(10-15 \mathrm{~cm})$ of silage was discarded, to limit risk of taking samples with anomalous fermentation. After that, two aliquots (about $1.5 \mathrm{~kg}$ each) were prepared for each sorghum silage, as a representative sample of the three mini-silos. The same protocol was followed on both farms. The first aliquot of each silage was sent to the laboratories of ARAV (Breeders Association of Veneto Region, Padova, Italy) to assay proximate composition, $\mathrm{pH}$, ammonia $\mathrm{N}$ content, and fermentation acid profile. Proximate analysis was conducted in triplicate according to AOAC (2012). The NDF fraction, inclusive of insoluble ash, was measured with Ankom ${ }^{220}$ Fibre Analyzer (Ankom Technology, NY, USA). Ammonia N content and $\mathrm{pH}$ were determined by a potentiometer equipped with a specific electrode ( $\mathrm{pH}$ meter BASIC 20, Crison Instruments, Alella, Spain). Fermentation acids were measured using a Thermo Finnigan Spectra System AS3000 auto-sampler (Thermo Electron Corporation, Waltham, MA, USA), equipped with an $\mathrm{H}_{2} \mathrm{SO}_{4} 0.0025 \mathrm{~N}$ BioRad HPX-87H column (Bio-Rad Laboratories, Richmond, CA, USA). The second aliquot of each silage was sent to the laboratories of the University of Padova. Once in the laboratories, samples were dried in a forced-air oven at $60^{\circ} \mathrm{C}$ for $48 \mathrm{~h}$, to determine DM content, and ground to 1-mm. Eight subsamples were prepared for each hybrid $\times$ farm combination and used for in vitro tests. Fermentations were conducted with Ankom ${ }^{R F}$ gas production (GP) system (Ankom Technology, NY, USA). This system is a kit of bottles $(310 \mathrm{ml})$ equipped with a pressure detector and wireless connection to a PC. Each bottle was filled with feed sample $(0.500 \pm 0.0010 \mathrm{~g}), 25 \mathrm{ml}$ of rumen fluid, and $50 \mathrm{ml}$ of buffer solution (ratio 1:2). Bottles were incubated at 39 $\pm 0.4^{\circ} \mathrm{C}$ for $48 \mathrm{~h}$ and vented at $3.4 \mathrm{kPa}$, to avoid overpressure conditions (Cattani et al., 2014). Two incubations were repeated in 2 successive weeks, and the following experimental design was applied: 3 hybrids $\times 2$ farms $\times 4$ replicates, plus 4 blanks (bottles without feed sample), giving a total of 28 bottles incubated in each of the two incubations. At the end of each incubation run, fermentation fluids were filtered into weighed crucibles (Robu Glasfilter-Geräte $\mathrm{GmbH}$, Hattert, Germany) and treated with a heat stable amylase, but without sodium sulphite, to assay residual NDF, using a Fibertech Analyzer (VELP Scientifica, Milan, Italy). Rumen fluid was collected by an esophageal probe, as detailed by Tagliapietra et al. (2012), from three intact dry Holstein-Friesian cows fed hay ad libitum and $2.5 \mathrm{~kg} / \mathrm{d}$ of concentrates. Buffer solution was prepared according to Menke and Steingass (1988). The degradability of NDF (NDFd) and of true DM (TDMd) were calculated as follows:

$$
\mathrm{NDFd}(\% \mathrm{NDF})=\left[\left(\mathrm{NDF}_{\text {feed }}-\mathrm{NDF}_{\text {res }}\right) / \mathrm{NDF}_{\text {feed }}\right] \times 100
$$

where:

$\mathrm{NDF}_{\text {feed }}$ is the NDF content $(\mathrm{g} / \mathrm{kg} \mathrm{DM})$ of feed incubated, $\mathrm{NDF}_{\text {res }}$ is the amount $(\mathrm{g} / \mathrm{kg} \mathrm{DM})$ of residual NDF. 
$\operatorname{TDMd}(\% \mathrm{DM})=\left[\left(\mathrm{DM}_{\text {feed }}-\mathrm{NDF}_{\text {res }}\right) / \mathrm{DM}_{\text {feed }}\right] \times 100$

where:

$\mathrm{DM}_{\text {feed }}$ is the DM content $(\mathrm{g} / \mathrm{kg})$ of feed incubated.

Metabolizable energy (ME) content of silages was computed from chemical composition and NDFd measured at $48 \mathrm{~h}\left(\mathrm{NRC}, 2001 ; \mathrm{ME}_{\mathrm{NRC}}\right)$ or GP measured at $24 \mathrm{~h}$ of incubation (Menke and Steingass, 1988; $\mathrm{ME}_{\text {Menke }}$ ). The two equations were the following:

$$
\mathrm{ME}_{\mathrm{NRC}}(\mathrm{MJ} / \mathrm{kg} \mathrm{DM})=-0.45 \times 4.184+1.01 \times \mathrm{DE}
$$

where:

$\mathrm{DE}$ is the digestible energy:

$$
\begin{aligned}
\mathrm{DE}(\mathrm{MJ} / \mathrm{kg} \mathrm{DM})= & {[(\mathrm{NDFd} / 1000) \times 4.2+(\mathrm{tdNFC} / 1000) \times 4.2+(\mathrm{tdCP} / 1000) \times} \\
& \times 5.6+(\mathrm{tdFA} / 1000) \times 9.5-0.3] \times 4.184
\end{aligned}
$$

where:

NDFd is the NDF degradability (g/kg NDF) measured at $48 \mathrm{~h}$,

tdNFC, tdCP and tdFA are the estimated true digestible contents of non-fibre carbohydrates, $\mathrm{CP}$ and $\mathrm{EE}$ ( $\mathrm{g} / \mathrm{kg} \mathrm{DM}$ ) calculated using the equations proposed by NRC (2001) (i.e., Eqs. 2-4a to 2-4e).

$$
\mathrm{ME}_{\text {Menke }}(\mathrm{MJ} / \mathrm{kg} \mathrm{DM})=2.20+0.1357 \times \mathrm{GP}_{2} 4_{200}+0.0057 \times \mathrm{CP}+0.0002859 \times \mathrm{EE}^{2}
$$

where:

$\mathrm{GP} 24_{200}$ is the gas production $(\mathrm{ml})$ measured at $24 \mathrm{~h}$ and referred to $200 \mathrm{mg}$ of feed sample,

$\mathrm{CP}=$ crude protein content $(\mathrm{g} / \mathrm{kg} \mathrm{DM}) ; \mathrm{EE}=$ ether extract content $(\mathrm{g} / \mathrm{kg} \mathrm{DM})$.

\section{Statistical analysis}

Data of silage composition (proximate analysis, $\mathrm{pH}$, fermentation acid profile, ammonia N) were subjected to analysis of variance using the general linear model procedure (PROC GLM) of SAS (SAS Institute Inc., Cary, NC, USA release 9.1). The statistical model considered effects of farm (2 levels: Farm 1 and Farm 2), hybrid (3 levels: Bulldozer, Surgo, and Favorite), and interaction between farm and hybrid $(\mathrm{F} \times \mathrm{H})$ as sources of variation. Other data (in vitro degradability, GP, and energy content of silages) were analyzed using a model that considered effects of farm, hybrid, $\mathrm{F} \times \mathrm{H}$ interaction, and, in addition, incubation run (2 levels: incubation 1 and incubation 2) as sources of variation. 


\section{Results}

The DM content of silages was on average greater in Farm 2 compared to Farm 1 (29.0 vs. $25.5 \%$, respectively; $\mathrm{P}<0.001$; Table 1 ). The proximate composition of silages reflected the plant genotype. The forage sorghum had the greatest NDF, ADF, and ADL contents $(P<0.001)$. On the other hand, the grain genotype showed the lowest fiber fraction, especially in Farm 1, and the highest starch content $(\mathrm{P}<0.001)$. As regards starch, the sweet genotype showed, on average, the lowest content in Farm 1 and intermediate values in Farm 2. Starch content of the sweet sorghum was, on average, three times greater on Farm 2 than on Farm 1 (13.2 vs. 4.4\% starch in Farm 2 and Farm 1, respectively). Final $\mathrm{pH}$ of silages was affected by farm, and hybrid $(\mathrm{P}<0.001$; Table 2$)$. In all silages lactate was the prevalent fermentation acid (on average $83.1 \%$ total fatty acids), followed by acetate (on average $16.7 \%$ total fatty acids); propionate was present only in traces and n-butyrate was never detectable by the GC. Total production of fermentation acids was influenced by hybrid $(\mathrm{P}<0.001)$, proving consistently lower for the forage genotype; in Farm 1 the sweet sorghum showed a lower acid production compared to the grain genotype, whereas the opposite tendency was observed in Farm $2(\mathrm{P}<0.001)$. The ratio between ammonia $\mathrm{N}$ and total $\mathrm{N}$ ranged from 2.97, for the sweet genotype of Farm 2, to $6.54 \%$ for the grain genotype of Farm 1. Values of NDFd were not influenced by hybrid and farm, and ranged from 50.2 to $57.3 \%$, for the grain and the forage sorghums grown in Farm 1 (Table 3). Compared to the other two hybrids, the sweet sorghum revealed an intermediate extent of NDF degradability in the Farm $1(\mathrm{NDFd}=54.5 \%)$ and the lowest value in the Farm $2(\mathrm{NDFd}=51.7 \%)$. Irrespective of the farm, the grain genotype showed the greatest values of TDMd, whereas the lowest in vitro "true" DM degradability was found for the forage genotype. As observed for NDFd, the sweet sorghum exhibited intermediate values of TDMd with respect to other hybrids. As regards the sorghums of Farm 1, the grain genotype showed the greatest values of in vitro GP $(\mathrm{P}<0.001$ and $\mathrm{P}<0.05$, at 24 and $48 \mathrm{~h}$, respectively); no differences were found between the other two hybrids (the forage and the sweet), either at $24 \mathrm{~h}$ or at $48 \mathrm{~h}$. A different ranking emerged for samples belonging to Farm 2, as the forage sorghum always had the lowest in vitro GP $(\mathrm{P}<0.001$ and $\mathrm{P}<0.05$, at 24 and $48 \mathrm{~h}$ of incubation, respectively), whereas the sweet sorghum showed an in vitro GP comparable to that of the grain genotype. In terms of energy content the sweet sorghum tended to be more similar to the forage genotype in the Farm 1 and to the grain genotype in the Farm 2. Values of $\mathrm{ME}_{\mathrm{N}}$ ${ }_{\mathrm{RC}}$ ranged from 8.9 (for the sweet genotype of Farm 1 and the forage genotype of Farm 2) to $10.1 \mathrm{MJ} / \mathrm{kg} \mathrm{DM}$ (for the grain genotype of Farm 2). Values of $\mathrm{ME}_{\text {Menke }}$ were on average lower than those calculated using NRC (2001) approach and ranged from 7.0 to $8.9 \mathrm{MJ} / \mathrm{kg}$ DM for the forage and the grain genotypes of Farm 1, respectively. 
Table 1. Chemical composition (\% DM) of three sorghum silages harvested in the two farms

\begin{tabular}{|c|c|c|c|c|c|c|c|c|}
\hline & $\mathrm{DM}$ & $\begin{array}{c}\text { Ether } \\
\text { extract }\end{array}$ & $\mathrm{CP}$ & NDF & $\mathrm{ADF}$ & ADL & Ash & Starch \\
\hline \multicolumn{9}{|l|}{ Farm 1} \\
\hline forage & $22.3 \mathrm{C}$ & $2.0 \mathrm{BC}$ & $8.2 \mathrm{BC}$ & $70.1 \mathrm{~A}$ & $41.9 \mathrm{~A}$ & $4.6 \mathrm{AB}$ & $6.9 \mathrm{AB}$ & $5.8 \mathrm{C}$ \\
\hline sweet & $22.8 \mathrm{C}$ & $2.1 \mathrm{BC}$ & $9.4 \mathrm{AB}$ & $62.1 \mathrm{~B}$ & $34.7 \mathrm{~B}$ & $3.7 \mathrm{BC}$ & $7.6 \mathrm{~A}$ & $4.4 \mathrm{C}$ \\
\hline grain & $31.3 \mathrm{~A}$ & $3.3 \mathrm{~A}$ & $10.2 \mathrm{~A}$ & $49.3 \mathrm{D}$ & $27.4 \mathrm{D}$ & $2.9 \mathrm{C}$ & $7.5 \mathrm{~A}$ & $15.8 \mathrm{~B}$ \\
\hline \multicolumn{9}{|l|}{ Farm 2} \\
\hline forage & $26.7 \mathrm{~B}$ & $2.1 \mathrm{BC}$ & $8.2 \mathrm{BC}$ & $72.0 \mathrm{~A}$ & $42.3 \mathrm{~A}$ & $5.2 \mathrm{~A}$ & $5.6 \mathrm{C}$ & $4.6 \mathrm{C}$ \\
\hline sweet & $26.6 \mathrm{~B}$ & $2.4 \mathrm{~B}$ & $8.7 \mathrm{BC}$ & $57.2 \mathrm{BC}$ & $32.8 \mathrm{BC}$ & $4.4 \mathrm{AB}$ & $6.4 \mathrm{BC}$ & $13.2 \mathrm{~B}$ \\
\hline grain & $33.6 \mathrm{~A}$ & $1.6 \mathrm{C}$ & $7.8 \mathrm{C}$ & $54.9 \mathrm{C}$ & $30.3 \mathrm{CD}$ & $3.9 \mathrm{AB}$ & $6.5 \mathrm{BC}$ & $20.0 \mathrm{~A}$ \\
\hline SEM $^{1}$ & 0.73 & 0.18 & 0.32 & 1.00 & 0.62 & 0.26 & 0.25 & 0.89 \\
\hline Farm (F) & $* * *$ & * & $* * *$ & ns & ns & $* * *$ & $* * *$ & $* * *$ \\
\hline Hybrid (H) & $* * *$ & ns & * & $* * *$ & $* * *$ & $* * *$ & $* *$ & $* * *$ \\
\hline $\mathrm{F} \times \mathrm{H}$ & $\mathrm{ns}$ & $* * *$ & $* *$ & $* * *$ & $* *$ & ns & ns & $* * *$ \\
\hline
\end{tabular}

Contrast significance is indicated $\mathrm{ns}=$ non-significant; $* \mathrm{P} \leq 0.05 ; * * \mathrm{P}<0.01 ; * * * \mathrm{P}<0.001$.

A, B, C, D - values in columns with different letters differ significantly $(\mathrm{P} \leq 0.01)$.

${ }^{1} \mathrm{SEM}=$ standard error of the mean.

Table 2. Silage $\mathrm{pH}$, total production of fermentation acids (FA; $\mathrm{g} / \mathrm{kg}$ as fed), proportion of acetate and lactate (\% total FA), and proportion of ammonia $\mathrm{N}$ on total $\mathrm{N}\left(\mathrm{N}-\mathrm{NH}_{3} / \mathrm{N}\right.$; expressed as percentage) of three sorghum silages harvested in the two farms

\begin{tabular}{|c|c|c|c|c|c|}
\hline & $\mathrm{pH}$ & Total FA & Acetate & Lactate & $\mathrm{N}-\mathrm{NH}_{3} / \mathrm{N}$ \\
\hline \multicolumn{6}{|l|}{ Farm 1} \\
\hline forage & $3.97 \mathrm{~A}$ & $14.4 \mathrm{~B}$ & $19.3 \mathrm{AB}$ & $80.7 \mathrm{DE}$ & $3.97 \mathrm{~B}$ \\
\hline sweet & $3.89 \mathrm{AB}$ & $15.6 \mathrm{~B}$ & $20.4 \mathrm{~A}$ & $79.5 \mathrm{E}$ & $5.35 \mathrm{~A}$ \\
\hline grain & $3.95 \mathrm{~A}$ & $18.2 \mathrm{~A}$ & $17.5 \mathrm{BC}$ & $82.4 \mathrm{CD}$ & $6.54 \mathrm{~A}$ \\
\hline \multicolumn{6}{|l|}{ Farm 2} \\
\hline forage & $3.74 \mathrm{CD}$ & $14.8 \mathrm{~B}$ & $13.5 \mathrm{D}$ & $86.3 \mathrm{~A}$ & $3.46 \mathrm{~B}$ \\
\hline sweet & $3.62 \mathrm{D}$ & $17.9 \mathrm{~A}$ & $14.1 \mathrm{D}$ & $85.6 \mathrm{AB}$ & $2.97 \mathrm{~B}$ \\
\hline grain & $3.81 \mathrm{~B} \mathrm{C}$ & $17.3 \mathrm{~A}$ & $15.6 \mathrm{CD}$ & $84.0 \mathrm{BC}$ & $3.64 \mathrm{~B}$ \\
\hline${ }^{1} \mathrm{SEM}$ & 0.032 & 0.34 & 0.56 & 0.56 & 0.317 \\
\hline Farm $(\mathrm{F})$ & $* * *$ & ns & $* * *$ & $* * *$ & $* * *$ \\
\hline Hybrid (H) & $* * *$ & $* * *$ & ns & ns & $* * *$ \\
\hline $\mathrm{F} \times \mathrm{H}$ & ns & $* * *$ & $* *$ & $* * *$ & $* *$ \\
\hline
\end{tabular}

Contrast significance is indicated $\mathrm{ns}=$ non-significant; $* \mathrm{P} \leq 0.05 ; * * \mathrm{P}<0.01 ; * * * \mathrm{P}<0.001$.

$\mathrm{A}, \mathrm{B}, \mathrm{C}, \mathrm{D}, \mathrm{E}-$ values in columns with different letters differ significantly $(\mathrm{P} \leq 0.01)$.

${ }^{1} \mathrm{SEM}=$ standard error of the mean. 
Table 3. In vitro degradability of NDF (NDFd, \%) and of true dry matter (TDMd, \%), in vitro gas production ( $\mathrm{ml} / \mathrm{g} \mathrm{DM})$, and metabolizable energy content $(\mathrm{MJ} / \mathrm{kg} \mathrm{DM})$, calculated according to NRC $\left(2001 ; \mathrm{ME}_{\mathrm{NRC}}\right)$ or to Menke and Steingass (1988; $\left.\mathrm{ME}_{\mathrm{Menk}}\right)$, of three sorghum silages harvested in the two farms

\begin{tabular}{|c|c|c|c|c|c|c|}
\hline & \multirow{2}{*}{ NDFd } & \multirow{2}{*}{ TDMd } & \multicolumn{2}{|c|}{ Gas production } & \multicolumn{2}{|c|}{ Energy value } \\
\hline & & & $24 \mathrm{~h}$ & $48 \mathrm{~h}$ & $\mathrm{ME}_{\mathrm{NRC}}$ & $\mathrm{ME}_{\text {Menke }}$ \\
\hline \multicolumn{7}{|l|}{ Farm 1} \\
\hline forage & $57.3 \mathrm{a}$ & $69.6 \mathrm{bc}$ & $156 \mathrm{~B}$ & $220 \mathrm{~B}$ & $9.1 \mathrm{ab}$ & $7.0 \mathrm{C}$ \\
\hline sweet & $54.5 \mathrm{abc}$ & $71.9 \mathrm{abc}$ & $181 \mathrm{~B}$ & $236 \mathrm{~B}$ & $8.9 \mathrm{~b}$ & $7.8 \mathrm{BC}$ \\
\hline grain & $50.2 \mathrm{c}$ & $75.5 \mathrm{a}$ & $214 \mathrm{~A}$ & $261 \mathrm{~A}$ & $9.7 \mathrm{ab}$ & $8.9 \mathrm{~A}$ \\
\hline \multicolumn{7}{|l|}{ Farm 2} \\
\hline forage & $52.0 \mathrm{bc}$ & $68.5 \mathrm{c}$ & $177 \mathrm{~B}$ & $237 \mathrm{~B}$ & $8.9 \mathrm{~b}$ & $8.0 \mathrm{AB}$ \\
\hline sweet & $51.7 \mathrm{bc}$ & $72.3 \mathrm{ab}$ & $219 \mathrm{~A}$ & $278 \mathrm{~A}$ & $9.6 \mathrm{ab}$ & $8.8 \mathrm{~A}$ \\
\hline grain & $55.7 \mathrm{ab}$ & $75.9 \mathrm{a}$ & $216 \mathrm{~A}$ & $273 \mathrm{~A}$ & $10.1 \mathrm{a}$ & $8.6 \mathrm{AB}$ \\
\hline SEM & 2.13 & 1.41 & 9.4 & 10.3 & 0.29 & 0.27 \\
\hline \multicolumn{7}{|l|}{ Incubation } \\
\hline 1 & 51.3 & 71.9 & 192 & 251 & 9.3 & 8.2 \\
\hline 2 & 54.4 & 72.7 & 195 & 251 & 9.5 & 8.2 \\
\hline SEM & 1.18 & 0.83 & 5.6 & 6.1 & 0.16 & 0.16 \\
\hline Farm (F) & ns & ns & $*$ & $*$ & ns & $*$ \\
\hline Hybrid (H) & ns & $*$ & $* * *$ & $* *$ & $*$ & $* *$ \\
\hline $\mathrm{F} \times \mathrm{H}$ & $*$ & ns & ns & ns & ns & $*$ \\
\hline Incubation & ns & ns & ns & ns & ns & ns \\
\hline
\end{tabular}

Contrast significance is indicated $\mathrm{ns}=$ non-significant; $* \mathrm{P} \leq 0.05 ; * * \mathrm{P}<0.01 ; * * * \mathrm{P}<0.001$.

$\mathrm{a}, \mathrm{b}, \mathrm{c}-$ values in columns with different letters differ significantly $(\mathrm{P} \leq 0.05)$.

$\mathrm{A}, \mathrm{B}, \mathrm{C}-$ as above for $\mathrm{P} \leq 0.01$.

${ }^{\mathrm{I}} \mathrm{SEM}=$ standard error of the mean.

\section{Discussion}

Results of this study provide evidence that silages obtained from different sorghum hybrids differed in terms of chemical composition, fermentation profile and nutritional value. In addition, the cultivation site (farm) exerted a notable effect on silage characteristics. The DM content was largely affected by hybrid and farm. Firstly, the genotype could have exerted an effect, as observed by others (Pesce et al., 2000; Bolsen et al., 2003). Secondly, pedological characteristics of experimental plots could have influenced DM accumulation in sorghum plants. More precisely, soils belonging to Farm 1 were characterized, on average, by a lower OM, nitrogen, and mineral contents (i.e. phosphorus and potassium) compared to those of Farm 2. Thirdly, an effect also could be attributed to irrigation, which occurred only on Farm 2, where silages showed a greater DM content. Sorghum is known to be a drought resistant plant (Sanchez et al., 2002); however, some authors (Carmi et al., 2006) found 
that plants responded positively to irrigation, with an increment of DM accumulation. Chemical composition of silages reflected substantially the hybrid genotype, with a greater NDF content for the forage sorghum and a greater starch content for the grain one. Up to now, data concerning chemical composition of sweet sorghum genotypes are scarce. However, on the basis of our results, it could be speculated that irrigation promoted grain filling in plants of the sweet sorghum grown in Farm 2, which showed a starch content three times greater than the plants cultivated in Farm 1, where irrigation did not occur. In line with our expectations, chemical differences led to different fermentation patterns during the ensiling process. However, good visual appearance, colour and odour of silages seemed to indicate a proper preservation. In support of that, $\mathrm{pH}$ values of silages were included in the expected range (3.48-4.50) reported by Gallardo and Gagiotti (2004). Likewise, the ratio between ammonia N and total $\mathrm{N}$ was always under the threshold of 7, which indicates a correct preservation of silages (Romero, 2004). Moreover, fermentation acid profile, dominated by lactate and acetate, was an index of proper ensiling into the mini-silos. Absence of significant effects due to the incubation run proves that the in vitro GP system used in this study has a satisfactory repeatability. The three sorghum genotypes showed different values of in vitro NDFd, and this confirmed data obtained in vivo, in situ, and in vitro by Di Marco et al. (2009). In line with previous findings (Pesce et al., 2000; Bolsen et al., 2003), the grain genotype showed the greatest values of TDMd and GP, as a result of greater starch content, whereas the forage sorghum showed the lowest values, as the fibrous fraction probably had a greater incidence on total DM degradability. In general, the sweet sorghum grown in Farm 1 had chemical characteristics and in vitro fermentative properties which were intermediate compared to the other two hybrids. However, the sweet sorghum seemed to be closer to the forage genotype in terms of DM and starch contents, in vitro GP, and energy value. Differently, the sweet sorghum grown in Farm 2 tended to be more similar to the grain genotype, especially in terms of in vitro fermentation properties and energy value.

The results of the present study would suggest that the cultivation and subsequent utilization of sorghum silages in ruminant feeding must necessarily consider the main peculiarities of each hybrid cultivated under different conditions. After ensiling, the sweet sorghum exhibited chemical characteristics and fermentative properties similar to those of the grain genotype, especially when plants were grown in irrigated fields. On this basis, silages obtained from sweet sorghum could be included in ruminant diets as total or partial replacement of corn silage, depending on the energy requirements of the animals. However, preliminary results presented in this paper should be validated in vivo.

\section{Acknowledgements}

This activity is part of Veneto Agricoltura Agency's project "Alternative crops rotation to contain diffusion of Diabrotica virgifera virgifera LeConte". The authors are grateful to the plant breeding companies, KWS Italia Spa and SIVAM Spa, for their kind support to the research, and to S. De Paoli (ARAV, Breeders Association of Veneto Region) for chemical analyses. 


\section{References}

AOAC (2012). Official Methods of Analysis, 19th ed., Association of Official Analytical Chemists, Arlington, VA, USA.

B ols en K.K., Moore K., Coblentz W.K., S i efers M.K., White J.S. (2003). Sorghum silage. In: Silage Science and Technology, L. Al-Amoodi (ed.). Madison, WI, USA, pp. 609-632.

Carmi A., Aharoni V., Edelste in M., Umiel N., Hagiladi A., Yos ef E., Nikbachat M., Zenou A., Miron J. (2006). Effects of irrigation and plant density on yield, composition and in vitro digestibility of a new forage sorghum variety, Tal, at two maturity stages. Anim. Feed Sci. Technol., 131: 120-132.

Cattani M., Tagliapietra F., Maccarana L., Hansen H.H., Bailoni L., Schiav o n S. (2014). Technical note: In vitro total gas and methane production measurements from closed or vented rumen batch culture systems. J. Dairy Sci., 97: 1736-1741.

Colombini S., Rapetti L., Colombo D., Galas s i G., Crovetto G.M. (2010). Brown midrib forage sorghum silage for the dairy cow: nutritive value and comparison with corn silage in the diet. Ital. J. Anim. Sci., 9: 273-277.

Colombini S., Galass i G., Crovet to G.M., Rapetti L. (2012). Milk production, nitrogen balance, and fiber digestibility prediction of corn, whole plant grain sorghum, and forage sorghum silages in the dairy cow. J. Dairy Sci., 95: 4457-4467.

Dann H.M., Grant R.J., Cotanch K.W., Thomas E.D., Ballard C.S., Rice R. (2008). Comparison of brown midrib sorghum-sudangrass with corn silage on lactational performance and nutrient digestibility in Holstein dairy cows. J. Dairy Sci., 91: 663-672.

Di Marco O.N., Ress i a M.A., Arias S., A ello M.S., Arzadun M. (2009). Digestibility of forage silages from grain, sweet and bmr sorghum types: Comparison of in vivo, in situ and in vitro data. Anim. Feed Sci. Technol., 153: 161-168.

Gallardo M., Gagi otti M. (2004). La reservas y lo deseable, calidad en forrajes conservados. Manual de actualización técnica. Merco Láctea, San Francisco, Córdova, Argentina.

M e n ke K.H., S t e in g a s s H. (1988). Estimation of the energetic feed value obtained from chemical analysis and gas production using rumen fluid. Anim. Res. Dev., 28: 7-55.

National Research Council (NRC) (2001). Nutrient Requirements of Dairy Cattle, 7th ed., National Academy Press, Washington, DC, USA.

P e s c e D.M.C., Goncalves L.C., Rodrigues N.M., B orges I., Rodrigues J.A.S. (2000). Percentage and loss of dry matter and in vitro dry matter digestibility of 20 sorghum genotypes silages. Arq. Bras. Med. Vet. Zootec., 52: 250-255.

R o m e r o L.A. (2004). Ensilaje de soja, calidad en forrajes conservados. Manual de actualización técnica, Merco Láctea, San Francisco, Córdova, Argentina, pp. 40-41.

Rym er C., Huntington J.A., Willi a m s B.A., Given s D.I. (2005). In vitro cumulative gas production techniques: History, methodological considerations and challenges. Anim. Feed Sci. Technol., 123-124: 9-30.

S a n che z A.C., S u bu dh i P.K., R o s e n ow D.T., N g u y e n H.T. (2002). Mapping QTLs associated with drought resistance in sorghum (Sorghum bicolor L. Moench). Plant Mol. Biol., 48: 71-726.

Śliwiński B., Brzóska F., W ęglarzy K., B ereza M. (2012). Effect of silage from maize and strip-cropped sorghum and maize on dairy cow's yield and milk composition. Ann. Anim. Sci., 12: $367-379$.

Tagliapietra F., Cattani M., Hindrichsen I.K., Hansen H.H., Colombini S., B a i lo n i L., S c hi a v o n S. (2012). True dry matter digestibility of feeds evaluated in situ with different bags and in vitro using rumen fluid collected from intact donor cows. Anim. Prod. Sci., 52: $338-346$.

Received: 30 VII 2015

Accepted: 24 XI 2015 